\title{
Association Between the Rh Blood Group and the Covid-19 Susceptibility
}

\author{
Esref ARAC ${ }^{1}$, Ihsan SOLMAZ ${ }^{1}$, Hasan AKKOC ${ }^{2}$, Suleyman DONMEZDIL ${ }^{3}$, \\ Zulkuf KARAHAN ${ }^{4}$, Safak KAYA ${ }^{5}$, Yılmaz MERTSOY', Mehmet Serdar YILDIRIM ${ }^{1}$, \\ Nazim EKIN ${ }^{1}$, Songul ARAC ${ }^{1}$, Cengiz DEMIR ${ }^{1}$
}

${ }^{1}$ University of Health Sciences, Diyarbakır Gazi Yasargil Training and Research Hospital, Department of Internal Medicine

${ }^{2}$ Dicle University, Faculty of Medicine, Department of Pharmacology

${ }^{3}$ University of Health Sciences, Diyarbakır Gazi Yasargil Training and Research Hospital, Department of Psychiatry

${ }^{4}$ University of Health Sciences, Diyarbakır Gazi Yasargil Training and Research Hospital, Department of Cardiology

${ }^{5}$ University of Health Sciences, Diyarbakır Gazi Yasargil Training and Research Hospital, Department of Infectious

Diseases and Clinical Microbiology

${ }^{6}$ University of Health Sciences, Diyarbakır Gazi Yasargil Training and Research Hospital,

Department of Orthopedics and Traumatology Diyarbakır, TURKEY

\begin{abstract}
We aimed to investigate whether there is a predisposition to COVID-19 with ABO and Rh blood group systems. This study was a retrospective study that investigate the patients admitted to our hospital between March 16 -May 20 due to Covid-19 pandemic and conducted with data revealed from the hospital Information Management System A total of 392 patients were included in this study, including 227 PCR test positive patients with blood group information in the system and 165 possible patients with CT findings in favor of Covid-19. Data from a blood group study conducted with 127091 people in our province in 2019 were used as a control group. In our study, a significant increase was observed in the blood group A in patients diagnosed with Covid-19, and a decrease was found in the blood groups B, AB and especially O. However, statistical analysis showed no significant difference between Covid-19 patients and healthy individuals in terms of $\mathrm{ABO}$ blood group system. When analyzed in terms of Rh blood group system, it was found that Rh positivity was statistically significantly higher in patients with Covid-19 $(p=0.000)$. Our study suggests that the Rh $(-)$ blood group is protective and the Rh (+) blood group is predisposed to Covid 19 significantly. We think that it is valuable because it is the first study to reveal the relationship between Covid-19 and blood type in our country and the only one to reveal the relationship between Covid-19 and $\mathrm{Rh}(+)$ in the world literature.
\end{abstract}

Keywords: Covid-19, ABO, Rh, Blood groups

ÖZET

Rh Kan Grubu ve CoVID-19 Duyarıı̆ı̆ı Arasındaki İlişki

Çalışmamızda ABO ve Rh kan grubu sistemleri ile COViD-19'a yatkınlık olup olmadığı araştırıması hedeflenmiştir. Bu çalışma 16 Mart20 Mayıs arasında hastanemize Covid-19 pandemisi nedeni ile başvuran hastaların Hastane Bilgi Yönetim Sisteminden elde edilen verileriyle yapıımış retrospektif bir araştırmadır. Çalışmamıza PCR testi pozitif 227 hasta ile BT bulguları Covid-19 lehine olan 165 olası hasta olmak üzere toplam 392 hasta dâhil edilmiștir. Kontrol grubu olarak ilimizde 2019 yllında 127091 kişi ile yapılan kan grubu çalışmasındaki veriler kullanılmıştır. Çalışmamızda Covid-19 tanılı hastalarda A kan grubunda artış görülmüş, O başta olmak üzere B ve AB kan gruplarında azalma tespit edilmiştir. Ancak yapılan istatistiksel analizde Covid-19 hastalar ile sağlıkı bireyler arasında ABO kan grubu sistemi açısından anlamlı fark görülmemiştir. Rh kan grubu sistemi açısından incelendiğinde Covid-19 tanılı hastalarda Rh pozitifliğinin istatistiksel olarak anlamlı düzeyde çok daha yüksek olduğu tespit edilmiştir $(p=0.000)$. Çalıșmamız Rh(-) kan grubunun koruyucu, $\mathrm{Rh}(+)$ kan grubunun yatkınlık oluşturduğunu belirgin olarak ortaya koyduğunu düşünmekteyiz. Ülkemizdeki Covid-19 ile kan grubu arasındaki ilişkiyi ortaya koyan ilk ve dünya literatüründe Covid-19 ile Rh(+)'liği arasında ilişkiyi ortaya koyan tek çalışma olduğundan değerli olduğunu düşünmekteyiz.

Anahtar Kelimler: Covid-19, ABO, Rh, Kan grubu 


\section{INTRODUCTION}

The coronavirus (Covid-19), which has been declared as a pandemic by the World Health Organization, is known to be a danger to individuals whose immune system is not strong. As risk factors according to literature information and clinical observations the patient's age, male sex and chronic diseases, especially hypertension observed. ${ }^{1}$ Although there are currently some parameters such as Ferritin, LDH, CRP that can predict the severity of the disease, there is no biological marker indicating susceptibility to disease. The general blood group system known as ABO discovered by Landsteiner is the blood system located on the surface of the erythrocyte, a type of cell identity determined by the antigenic structure. However, in addition a grouping known as the Rh system, which is evaluated as the presence or absence of antigenic structure, is used. ${ }^{2}$ The phenotypic variation, in which blood groups have zero environmental impact, is a qualifier that is entirely a reflection of the genetic structure. Blood group antigens are genetically coded and these antigens can be susceptibility factors to some diseases and resistance factors for others. Blood group antigens are genetically coded and these antigens can be susceptibility factors to some diseases and resistance factors for others. In studies, ABO blood group system has been shown to be associated with Rheumatologic diseases and viral diseases such as Norwalk virus and Hepatitis B. ${ }^{3-6}$ It has also been found that the rate of being infected with SARS coronavirus is less than in the blood group of O. ${ }^{7}$

When the literature is examined, there is only one study that examined the relationship between Covid-19 and blood group that conducted by Jiao Zhao et al. ${ }^{1}$ made in China In this study, we aimed to investigate whether there is a predisposition to Covid-19 with $\mathrm{ABO}$ and $\mathrm{Rh}$ blood group systems.

\section{PATIENTS AND METHODS}

This study was a retrospective study that investigate the patients admitted to Diyarbakır Gazi Yaşargil Training and Research Hospital between March 16 - May 20 due to Covid-19 pandemic and conducted with data revealed from the hospital Information Management System. During this period, 1043 pa- tients were admitted to the hospital under suspicion of Covid-19, out of which 725 patients with CT findings, laboratory values, symptoms or history of contact with Covid-positive patients were admitted with a possible diagnosis of Covid-19. A total of 392 patients were included in this study, including 227 PCR test positive patients with blood group information in the system and 165 possible patients with CT findings in favor of Covid-19. Data from a blood group study conducted with 127091 people in our province in 2019 were used as a control group. ${ }^{8}$

The possible case was defined as the PCR test for the SARS-CoV-2 virus was described as negative but patients with symptoms, CT findings and a history of contact.

Definitive case was confirmed cases by laboratory PCR test that show SARS CoV-2 infection regardless of whether it has clinical signs and symptoms.

The ethics committee approval for the study was obtained from the ethics committee of Gazi Yaşargil Training and Research Hospital on 28.04.2020 with number 454 . This study conducted in accordance with the current Declaration of Helsinki."

\section{Statistical Analysis}

Statistical evaluation was performed using SPSS 22 for Windows (IBM SPSS Inc., Armonk, NY, USA). Chi-square test was used for the comparison of categorical data. $\mathrm{p}<0.05$ was considered statistically significant.

\section{RESULTS}

The blood group distribution of normal individuals in our province was $\mathrm{A}, \mathrm{B}, \mathrm{O}, \mathrm{AB} ; 39.7 \%, 18.6 \%$, $33.6 \%$ and $8.1 \%$, respectively. Rh (+) was $88.4 \%$ and $\mathrm{Rh}(-)$ was $11.6 \%$.

The blood group distribution of 227 patients diagnosed with PCR positivity as A, B, O, AB was $41.40 \%, 18.94 \%, 31.27 \%$ and $8.37 \%$ respectively. $\mathrm{Rh}(+)$ was $94.71 \%$ and $\mathrm{Rh}(-) 5.28 \%$.

When the blood groups of the patients with a definite diagnosis and the normal individuals taken as a control group were compared, there was a signifi- 


\begin{tabular}{|lllll|}
\hline \multicolumn{5}{|c|}{ Table 1. Covid-19 } \\
\hline
\end{tabular}

cant increase in the A blood group and a decrease especially in the $\mathrm{O}$ group, additionally $\mathrm{B}$ and $\mathrm{AB}$ blood groups those with Covid-19. However, there was no significant difference between Covid-19 patients and healthy individuals in terms of $\mathrm{ABO}$ blood group system In terms of Rh blood group system, it was determined that Rh positivity was significantly higher in patients with Covid-19 diagnosis $(\mathrm{p}=0.003)$ (Table 1).

With a definite and probable Covid-19 diagnosis, the blood group distribution of 392 patients A, B, $\mathrm{O}, \mathrm{AB}$ rates was determined as $42.60 \%, 19.13 \%$, $31.88 \%$ and $6.37 \%$, respectively. The $\mathrm{Rh}(+)$ patient ratio is $96.42 \%$ and the $\mathrm{Rh}(-)$ patient ratio is $3.57 \%$. Although there were percentile differences in $\mathrm{ABO}$ blood group distribution compared to healthy individuals, this was not statistically significant. However, in terms of Rh factor, Rh positivity was found to be significantly higher in Covid-19 patients $(\mathrm{p}=0.000)$ (Table 2).

\section{DISCUSSION}

Numerous studies have been published to date on the relationship between blood groups and diseases. ., $, 9,10$ These studies include Hepatitis B, Hepatitis C, HIV, West Nile Virus, SARS CoV and SARS $\mathrm{CoV}-2$ viruses. ${ }^{1,4,7,11}$ In all these studies raised an issue that some blood groups may be susceptible to viral infections and some groups may be protective. Although many models of this predisposition or protectionism have been established, the mechanism has not been fully elucidated and has been suggested as possible causes. Natural antibodies of the ABO system to block the interaction of SARS CoV spike protein and angiotensin converting enzyme 2 may be considered as one of the reasons suggested. ${ }^{12}$ Some studies show that the $\mathrm{ABO}$ blood group antigen improves the overall inflammatory response. Single nucleotide polymorphisms at the ABO locus have been found to increase levels of two important serum inflammation markers, TNF- $\alpha$ and soluble intercellular adhesion molecule-1 (ICAM-1), and the increase of TNF- $\alpha$ causes inflammation. ${ }^{13-15}$

It has been shown in studies that individuals with $\mathrm{O}$ blood type have a lower risk of being infected with SARS CoV and SARS CoV-2 viruses, and that individuals with A blood type are more frequently infected ${ }^{1,12}$ SARS-CoV infects cells that express $\mathrm{ABH}$ antigens according to an individual's $\mathrm{ABO}$ phenotype. SARS-CoV infection has been shown in pneumocytes, enterocytes of the small intestine, and distal tubular epithelial cells of the kidney, all cell types known to be able to synthesize $\mathrm{ABH}$ antigens. ${ }^{12}$

Despite being the gold standard for detecting Covid-19 disease, RT-PCR is believed to have a low sensitivity, especially in the early stages of the disease. Since radiological examinations show disease-related involvement in the lungs starting from the early stages of the disease, they are widely used in every suspected case and have become a part of the diagnostic process algorithm for suspected cases in terms of the Covid-19 disease. Direct chest imaging, which is the first radiological examination to be performed for cases admitted to the health institutions due to disease symptoms or contact history, has low sensitivity for the Covid-19 
International Journal of Hematology and Oncology

\begin{tabular}{|c|c|c|c|c|}
\hline & $\begin{array}{l}\text { COVID-19 PCR (+) } \\
\text { n (\%) }\end{array}$ & $\begin{array}{l}\text { Distribution of blood types } \\
\text { in Diyarbakir society } n(\%)\end{array}$ & $x^{2}$ & p \\
\hline A blood Type & 167 (42.60) & 50449 (39.6) & 1.379 & 0.240 \\
\hline B blood Type & 75 (19.13) & 23678 (18.6) & 0.065 & 0.799 \\
\hline O blood type & $125(31.88)$ & 42728 (33.6) & 0.525 & 0.469 \\
\hline AB blood type & $25(6.37)$ & 10236 (8) & 1.484 & 0.223 \\
\hline Rh positive & 378 (96.42) & $112390(88.4)$ & 24.470 & 0.000 \\
\hline Rh negative & $14(3.57)$ & $14701(11.5)$ & 24.470 & 0.000 \\
\hline
\end{tabular}

disease. ${ }^{16}$ In cases with no or unclear findings, it is recommended to perform an additional high-dose CT with no contrast, preferably thin section (volumetric and $1 \mathrm{~mm}$ cross-section spacing). In light of the clinical, laboratory and radiological data shared from the beginning of the pandemic to the present day, it is understood that some of the CT findings have a high sensitivity for the disease, but with relatively low specificity, as in other diseases. ${ }^{17,18}$ Although not specific to the disease, generally accepted signs and patterns have been identified in typical radiological findings. The most common among these are the large number of ground-glass opacities with a peripheral placement, usually in the lower and middle zones, often accompanied by septal thickening. Other findings include consolidations within ground-glass opacities, enlarged vessel sign, halo or inverted halo signs, and cobblestone-like appearance. ${ }^{19}$ Radiological findings to be considered for an additional pathology of for the exclusion of the disease are well-defined, and classified in the atypical category in terms of the disease. The most important of these are lobar consolidation, budded tree signs, isolated pleural effusion, unilateral involvement and upper zone involvement. ${ }^{17}$ PCR-positive patients and patients with typical signs of Covid-19 disease, in terms of the radiological criteria listed above, were included in our study (Figure 1A, B, C).

In our study, it was determined that the proportion of patients that had Covid-1 with O blood type was less and the A blood group was more than the population but no statistical significance was found. However, in all Covid-19 diagnosed patient espe- cially in PCR positive patients, the $\mathrm{Rh}(+)$ ratio was found to be significantly higher than the community ratio. Our study suggests that the Rh (-) blood group is protective and the $\mathrm{Rh}(+)$ blood group is predisposed to Covid-19 significantly.

The Rh (Rhesus) blood group system is the most complex of known human blood group polymorphisms. Expression of their antigens is controlled by a two-component genetic system consisting of RH and RHAG locus encoding Rh30 polypeptides and Rh50 glycoprotein, respectively. ${ }^{20}$ West Nile virus infection is more common in Rh-negative individuals, a hypothesis posits that glycosylated structures expressed differently on the surface of erythrocytes will facilitate virus binding or serve as receptors/ co-receptors through glycan-glycan or lectin-glycan interactions in a Velcro-like interaction. ${ }^{11}$ However, natural antibodies can block or opsonize the entry of viral particles leading to complement-mediated neutralization. ${ }^{21}$ It has also recently been shown that natural antibodies can aid the formation of cytotoxic $\mathrm{T}$ cells against the pathogen. ${ }^{22}$ These additional protection mechanisms may have contributed to the protection of that individual's blood group during the Covid-19 outbreak.

With many of the above-mentioned mechanisms, it is obvious that the virus infections show affinity to some blood groups or may be protective. Although the mechanism is unknown, this study suggests an association between $\mathrm{Rh}(\mathrm{D})$ positive blood groups and Covid-19 pathogenesis in terms of potential risk factors. 

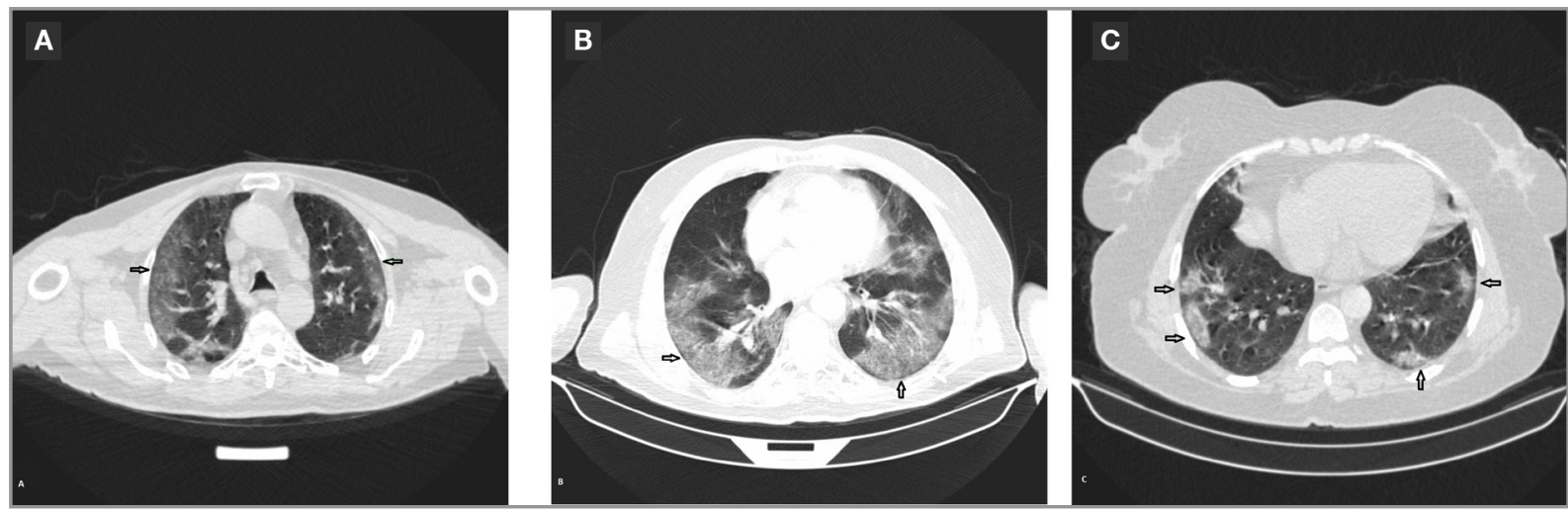

Figure 1A, B, C. Thorax CT was performed in a 74-year-old male patient who was admitted to the emergency department with shortness of breath and severe cough and in the lung, bilateral, multiple, upper, middle and lower zones, predominantly posterior and peripherally located, ground glass densities and occasional minimal consolidations are observed. (arrows)

In our study, the low number of cases, especially the high false negativity of PCR results and the failure to reach all PCR results due to some limitations may be reported as limitations of the study. However, we think that it is valuable because it is the first study to reveal the relationship between Covid-19 and blood type in our country and the only one to reveal the relationship between Covid-19 and $\mathrm{Rh}(+)$ in the world literature.

If this relationship is clearly established, it may be beneficial to control the number of cases by providing more attention to individuals with a $\mathrm{Rh}(+)$ blood type and chronic disease such as male sex, hypertension, which is determined in terms of protection from Covid-19.

\section{Acknowledgements}

Thank you to Dr.Şeyhmus Kaya for their radiological support.

\section{REFERENCES}

1. Zhao J, Yang $\mathrm{Y}$, Huang $\mathrm{H}$, et al. Relationship between the ABO blood group and the COVID-19 susceptibility. medRxiv 2020. doi: 10.1101/2020.03.11.20031096

2. Sayli BS. Temel Medikal Genetik. Ankara, Ankara Üniversitesi Tip Fakültesi Yayinlari, 1982: 430.

3. Lindesmith L, Moe C, Marionneau S, et al. Human susceptibility and resistance to Norwalk virus infection. Nat Med 9: 548553, 2003
4. Batool Z, Durrani SH, Tariq S. Association of $A B O$ and Rh blood group types to hepatitis $\mathrm{B}$, hepatitis $\mathrm{C}, \mathrm{HIV}$ and syphilis infection, a five year' experience in healthy blood donors in a tertiary care hospital. J Ayub Med Coll Abbottabad 29: 90-92, 2017.

5. Araç E, Solmaz I. Evaluation of blood groups in patients with anti TPO positive. Asian J Med Sci 10: 67-70, 2019.

6. Pelzer U, Klein F, Bahra M, et al. Blood group determinates incidence for pancreatic cancer in Germany. Front physiol 4: 118, 2013.

7. Cheng $\mathrm{Y}$, Cheng $\mathrm{G}$, Chui $\mathrm{CH}$, et al. $\mathrm{ABO}$ blood group and susceptibility to severe acute respiratory syndrome. JAMA 293: 1450-1451, 2005.

8. Arac E, Solmaz I, Samanci S. ABO and Rh blood groups frequency in men, women and neonates in Diyarbakir province. Ann Med Res 26: 2876, 2019.

9. Anstee DJ. The relationship between blood groups and disease. Blood 115: 4635-4643, 2010.

10. Teshome Y, Mekonen W, Birhanu Y, Sisay T. The association between $\mathrm{ABO}$ blood group distribution and peptic ulcer disease: a cross-sectional study from Ethiopia. J Blood Med 10: 193-197, 2019.

11. Kaidarova Z, Bravo MD, Kamel HT, et al. Blood group A and D negativity are associated with symptomatic West Nile virus infection. Transfusion 56: 1699-1706, 2016.

12. Guillon $P$, Clément $M$, Sébille $V$, et al. Inhibition of the interaction between the SARS-CoV Spike protein and its cellular receptor by anti-histo-blood group antibodies. Glycobiology 18: 1085-1093, 2008.

13. Paré G, Chasman DI, Kellogg M, et al. Novel association of ABO histo-blood group antigen with soluble ICAM-1: Results of a genome-wide association study of 6,578 women. PLoS Genetics 4(7):e1000118, 2008. 
International Journal of Hematology and Oncology

14. Melzer D, Perry JRB, Hernandez D, et al. A genome-wide association study identifies protein quantitative trait loci (pQTLs). PLoS Genetics 4(5):e1000072, 2008.

15. Park EJ, Lee JH, Yu GY, et al. Dietary and Genetic Obesity Promote Liver Inflammation and Tumorigenesis by Enhancing IL-6 and TNF Expression. Cell 140: 197-208, 2010.

16. Yoon SH, Lee KH, Kim JY, et al. Chest radiographic and ct findings of the 2019 novel coronavirus disease (Covid-19): Analysis of nine patients treated in korea. Korean J Radiol 21: 498-504, 2020.

17. Dai WC, Zhang HW, Yu J, et al. CT imaging and differential diagnosis of COVID-19. Can Assoc Radiol J 71: 195-200, 2020.

18. Li Y, Xia L. Coronavirus Disease 2019 (COVID-19): Role of Chest CT in Diagnosis and Management. AJR Am J Roentgenol 214: 1280-1286, 2020.

19. Ye Z, Zhang Y, Wang Y, et al. Chest CT manifestations of new coronavirus disease 2019 (COVID-19): a pictorial review. Eur Radiol 1-9, 2020

20. Huang CH, Liu PZ, Cheng JG. Molecular biology and genetics of the Rh blood group system. Semin Hematol 37: 150-165, 2000.

21. Neil SJD, McKnight A, Gustafsson K, Weiss RA. HIV-1 incorporates $\mathrm{ABO}$ histo-blood group antigens that sensitize virions to complement-mediated inactivation. Blood 105: 4693-4699, 2005.

22. Dürrbach A, Baple $E$, Preece AF, et al. Virus recognition by specific natural antibodies and complement results in $\mathrm{MHC}$ I cross-presentation. Eur J Immunol 37: 1254-1265, 2007.

\section{Correspondence:}

Dr. Esref ARAC

Saglik Bilimleri Üniversitesi

Diyarbakir Gazi Yasargil Egitim ve Arastirma Hastenesi

Ic Hastaliklari Anabilim Dali

DIYARBAKIR / TURKEY

Tel: (+90-541) 3581330

Fax: (+90-412) 2580060

e-mail: esref.arac@sbu.edu.tr

\section{ORCIDs:}

Esref Arac:

Ihsan Solmaz:

0000-0001-6041-3817

0000-0002-6624-8063

Hasan Akkoc:

0000-0003-2836-2452

Suleyman Donmezdil:

Zulkuf Karahan:

0000-0002-7171-1374

Safak Kaya:

0000-0001-8148-9574

Yilmaz Mertsoy:

0000-0001-9422-1346

Mehmet Serdar Yildirim:

0000-0001-9912-7340

0000-0003-3967-9826

Nazim: Ekin

0000-0001-5302-8953

Songül Arac:

0000-0001-6830-3639

Cengiz Demir: 